\section{Shipwreck fouls the water}

\section{Berkeley}

THE largest oil-tanker spill in US history has turned Alaska's Prince William Sound from a pristine environment into a disaster area. Biologists are not yet able to assess the full extent of the damage to the area's wildlife, but the political damage to those pressing for further oil development in Alaska is already plain.

On 24 March, the fully-loaded oil tanker Exxon Valdez struck a reef shortly after leaving the Alaskan pipeline terminal in Valdez, southern Alaska, spilling 10 million gallons of crude oil. The tanker's captain, who had been drinking before the accident, had left the ship in the hands of a crewman not certified to pilot the ship within the sound.

Little oil from the spill was recovered, and angry fishermen and environmentalists blame Exxon and the Alyeska Pipeline Service Company, which manages the pipeline, for a disorganized clean-up effort that squandered precious time. Floating booms intended to be deployed quickly to contain a spill did not reach the site until more than 10 hours after the wreck, said Jon Lyman, of the Alaska Department of Fish and Game. Alyeska officials blamed the delay on the fact that the barge intended to carry the booms was unloaded for repairs.

Alyeska spokeswoman Beverly Michaels said that skimmers and booms are not practical for such a large spill, and Alyeska was prepared on the day after the spill to apply chemicals that disperse the oil into the water. But fishermen, concerned about the toxic effects of the dispersants and dissolved oil, persuaded the Coast Guard to delay permission to use them. By the time permission was received the following day, said Michaels, high winds made it impossible to apply the dispersant from aircraft. Debate still continues over whether dispersants or containment and collection would have been best, but after two days of heavy winds the oil was spread over 550 square miles, ruling out either method. Fishermen and state officials joined Exxon and Alyeska in using barriers to protect the most environmentally sensitive areas.

Because the Valdez spill is in a relatively enclosed area, it formed a continuous blanket over the water, potentially trapping aromatic hydrocarbons, such as benzene or toluene, in the water beneath the oil. Jacqueline Michel, an environmental chemist for the National Oceanic and Atmospheric Administration (NOAA), said laboratory studies have shown such chemicals to be highly toxic to planktonic fauna.

The herring-roe fishery will be the first influenced by the spill. Within the next few weeks, the fishery would normally begin to capture herring that have entered the sound to spawn, and allow them to deposit their eggs on kelp, which is harvested after the fish are released. Sale of this year's harvest may be banned if hydrocarbon contamination is detected in the spawning areas or in the roe that is collected.

High priority was given to protecting the economically important hatcheries where young salmon are raised and returned to the sea in May. Some are tagged each year before release, and survival data are collected when the adults are caught by fishermen several years later. Tags from those released this year will provide information on the impact of the spill on the salmon population.

Lyman said that birds and sea otters are particularly vulnerable to oil spills, because the oil destroys the insulating qualities of their fur and feathers. Exxon brought in an animal rescue team from California, but rescue attempts were hindered by the inaccessibility of the rocky beaches in the area. Tens of thousands of birds and otters live in the sound, and many of those are likely to have been harmed or killed by the oil, but a week after the spill only a handful had been rescued and cleaned. The cleaned animals will be tagged before their release, to aid biologists in determining the fate of animals following the spill.

Migratory puffins, terns, cormorants and other birds are just beginning to enter the area. Their nesting grounds, as well as the areas where sea lions will give birth in May, were included among areas to be protected with booms from the progressing oil slick.

Exxon will hire local residents to clean oil from hundreds of miles of shoreline. Exxon spokesman Brian Dunphy said absorbent pads will be used to soak up the oil, and high-pressure hoses will blast it off rocks. Michel, of NOAA, said wave action and biological activity will purge the oil from exposed sites, but sheltered areas may remain contaminated for years.
Cuba signs agreement with Soviet Union

\section{London}

CUBA has signed a nuclear safety agreement with the Soviet Union, regulating Soviet assistance at the Cienfugos nuclear plant and "other nuclear projects" under construction. The Soviet side is to equip Cuban nuclear safety laboratories with services, hardware and documentation, and will also arrange consultancy services on how to organize radiation monitoring. Cubans will be trained in the Soviet Union as operators of nuclear power stations.

Vera Rich

The spill is likely to cause political fallout, as the battle continues in Congress over oil development in the Arctic National Wildlife Refuge, adjacent to the Prudhoe Bay area which now supplies oil to the Alaskan pipeline. Environmental groups have opposed the development (see Nature 327, 9; 1987), while oil companies and the Bush administration have argued that development is essential, and can be conducted in an "environmentally sensitive" manner. The Valdez spill did not change administration policy, but environmental groups expect its effects on public opinion to be felt in Congress, where competing bills are being considered that would either open the area for development or declare it a wilderness area, thus preventing oil drilling. Opponents of oil development off the California coast expect the spill to aid their cause as well.

Although an oil spill at the pipeline terminal is not the same as the general environmental disruption feared from construction of oil exploration sites in the Alaskan wildlife refuge, Don Hellmann, of the Wilderness Society, said it raises the question of whether assurances from oil companies can be trusted. "The oil companies have been saying all along that they can drill without harming the environment, and if there is a problem such as a spill, they can take care of it right away. Now we've seen that they're wrong on both counts."

Marcia Barinaga

\section{UNAVAILABLE FOR COPYRIGHT REASONS}

